\title{
Pengukuran Tegangan, Arus, Daya Pada Prototype PLTS Berbasis Mikrokontroller Arduin Uno
}

\author{
Abdul Makruf, Rizal Rahmadhani, Pratika Sulistya Ningsih, Wiki Jayaditama, Nur Rani \\ Alham. \\ Jl. Sambaliung no.9 Kampus Gunung Kelua Samarinda - Indonesia \\ Program Studi Teknik Elektro, Fakultas Teknik, Universitas Mulawarman \\ Email: pratikasulistyaningsih0204@gmail.com
}

\begin{abstract}
Abstrak
Energi pada saat ini mempunyai peranan yang sangat penting dalam kehidupan manusia. Selama ini penyangga utama kebutuhan energi masih mengandalkan minyak bumi. Sementara itu tidak dapat dihindarkan bahwa minyak bumi semakin langka dan mahal harganya. Dengan keadaan semakin menipisnya sumber energi fosil tersebut, di dunia sekarang ini terjadi pergeseran dari penggunaan sumber energi tak terbaharui menuju sumber energi terbaharui. Dari sekian banyak sumber energi terbahurui penggunaan energi melalui solar cell / sel surya merupakan alternatif yang paling potensial untuk diterapkan di wilayah Indonesia. Energi surya merupakan salah satu energi yang sedang giat dikembangkan saat ini oleh pemerintah Indonesia karena sebagai negara tropis, Indonesia mempunyai potensi energi surya yang cukup besar. Saat ini PLTS masih digolongkan sebagai pembangkit listrik dengan investasi awal yang mahal, Oleh karena itu, pemasangan PLTS lebih diutamakan untuk penerangan. Untuk keperluan tersebut penggunaan lampu yang memerlukan daya rendah sangatlah penting. Lampu Light Emitting Diode (LED) DC hemat energi merupakan salah satu solusi yang dapat diterapkan untuk mengatasai masalah penerangan di daerah terpencil yang mendapat suplay energi dari PLTS. Dengan adanya penerangan dapat menunjang aktivitas sosial, ekonomi dan pendidikan masyarakat terutama pada malam hari.
\end{abstract}

Kata kunci : Energi surya, sel surya, PLTS.

\begin{abstract}
Energy at the moment have the very important role in human life. During the time especial prop of requirement energy still rely on the petroleum. Meanwhile cannot be obviated that scarce petroleum progressively costly. With the circumstance progressively attenuate the source fossil energy the world is happened by the friction from use of source energy do not be updated to go to the source energy updated. Solar energy used represent the most potential alternative to be applied in Indonesia region. Solar energy represents one of energy which developed impetuous medium in this time by Indonesia government because as tropical state. Indonesia has the big enough potency solar energy. Currently, PLTS is still classified as a power plant with an expensive initial investment. Therefore, installing PLTS is preferred for lighting. For these purposes, the use of lamps that require low power is very important. Energy-saving Light Emitting Diode (LED) DC lights are one solution that can be applied to overcome lighting problems in remote areas that receive energy supplies from PLTS. With lighting, it can support social, economic and community education activities, especially at night.
\end{abstract}

Keywords : Solar energy, solar cell, PLTS.

\section{PENDAHULUAN}

Energi merupakan kebutuhan utama sepanjang peradaban umat manusia. Peningkatan kebutuhan energi dapat menjadi indikator peningkatan kemakmuran, namun pada saat yang sama menimbulkan masalah dalam usaha penyediaannya. Dengan kian menipisnya cadangan minyak bumi di Indonesia, pemanfaatan energi alternatif nonfosil harus 
ditingkatkan. Ada beberapa energi alam sebagai energi alternatif yang bersih, tidak berpolusi, aman dan persediaannya tidak terbatas yang dikenal dengan Energi terbarukan. Diantaranya adalah energi surya, angin, gelombang dan perbedaan suhu air laut [1], [2]. Selama ini penyangga utama kebutuhan energi masih mengandalkan minyak bumi, sementara itu tidak dapat dihindarkan bahwa minyak bumi semakin langka dan mahal harganya. Cadangan sumber energi fosil di seluruh dunia terhitung sejak 2002 yaitu 40 tahun untuk minyak, 60 tahun untuk gas alam, dan 200 tahun untuk batu bara [3]. Dengan keadaan semakin menipisnya sumber energi fosil tersebut [4], di dunia sekarang ini terjadi pergeseran dari penggunaan sumber energi tak terbaharui menuju sumber energi terbaharui. Potensi energi terbarukan, seperti: biomassa, panas bumi, energi surya, energi air, energi angin, energi samudera, hydro power sampai saat ini belum banyak dimanfaatkan, padahal potensi energi terbarukan ini sangatlah besar khususnya di Indonesia.

Dari sekian banyak sumber energi terbaru seperti diatas penggunaan energi melalui solar cell / sel surya merupakan alternatif yang paling potensial untuk diterapkan di wilayah Indonesia. Peningkatan kebutuhan energi dapat merupakan indikator peningkatan kemakmuran, namun bersamaan dengan itu juga menimbulkan masalah dalam usaha penyediaannya. Pemakaian energi surya di Indonesia mempunyai prospek yang sangat baik, mengingat bahwa secara geografis sebagai negara tropis, melintang garis katulistiwa berpotensi energi surya yang cukup baik. Tenaga surya memiliki beberapa keuntungan antara lain energinya tersedia secara cuma-cuma, perawatannya mudah dan tidak ada komponen yang bergerak sehingga tidak menimbulkan suara/kebisingan, serta mampu bekerja secara otomatis. Akan tetapi tenaga surya juga memiliki kendala yaitu energi yang dihasilkan tergantung pada intensitas cahaya matahari yang tidak tersedia 24 jam sehari sehingga diperlukan suatu media penyimpanan energi berupa baterai sebagai sumber pada saat intensitas cahaya menurun atau bahkan tidak ada sama sekali. Telah banyak penelitian dilakukan berkaitan dengan energi surya [5]-[8].

Kebutuhan manusia akan sumber energi menjadikan ketergantungan manusia terhadap sumber daya alam semakin besar, populasi manusia kian lama kian bertambah banyak. Sementara sumber daya alam kian lama kian menyusut minyak bumi, batu bara, gas alam, nuklir adalah sumber daya alam untuk pemanfaatan energi yang sangat besar. Sumber energi ini masih menjadi sumber utama pemberdayaan energi untuk kebutuhan manusia. Hingga saat ini para ahli mencoba mencari sumber energi baru yang dapat memenuhi kebutuhan energi, yang memenuhi sifat ramah lingkungan dan mudah di dapat. Panas matahari sebagai sumber panas yang bersifat abadi menjadi salah satu pilihan yang baik untuk dijadikan sebagai sumber energi terutama untuk pemanfaatan energi listrik [9].

\section{METODE PENELITIAN}

\subsection{Studi Literatur}

Studi literatur yang digunakan pada jurnal ilmiah ini adalah berdasarkan acuan jurnal ilmiah, buku, serta e-book yang terkait pada judul jurnal ini.

\subsection{Penentuan Parameter Uji}

Parameter uji yang digunakan adalah dengan membandingkan data daya pada waktu satu jam dan dua jam dengan beban dan tanpa beban.

\subsection{Diagram Alur Penelitian}

Diagram alur penelitian adalah seperti pada Gambar 1.

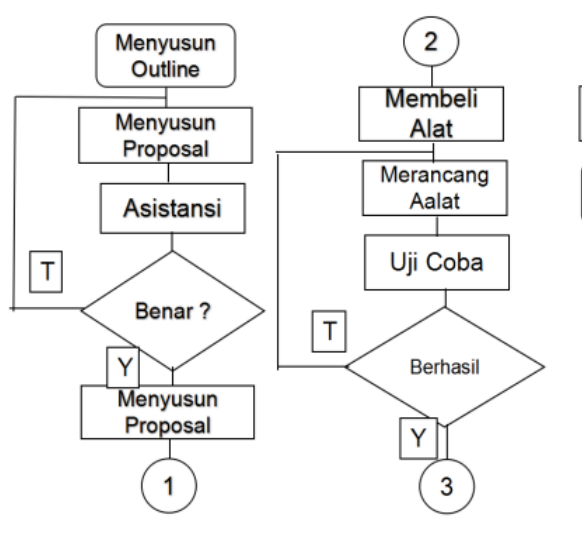

Gambar 1. Diagram Alur Penelitian

\subsection{Spesifikasi}

Berikut merupakan spesifikasi komponen yang diperlukan:

\subsubsection{Sel Surya}


SainETIn (Jurnal Sain, Energi, Teknologi \& Industri), Vol. 5 No. 1, Desember 2020, pp. 8 - 16 ISSN 2548-6888 print, ISSN 2548-9445 online

Sel surya merupakan alat yang berbahan semikonduktor yang terdiri dari dioda pertemuan $\mathrm{p}-\mathrm{n}$, yang memberikan efek fotovoltaik yaitu pengubahan sinar matahari dan menghasilkan energi listrik. Berikut spesifikasi PV :

1. Tegangan Optimal $(\mathrm{Vmp})=18.52 \mathrm{~V}$

2. Arus Optimal $(\operatorname{Imp})=0.54 \mathrm{~A}$

3. Dimensi Cell $=0.35 \times 0.29=0.1015 \mathrm{~m}^{2}$

4. Koefsien incident radiation flux $=1000 \mathrm{~W} / \mathrm{m}^{2}$

5. $\mathrm{TC}$ atau suhu cell $=25^{\circ} \mathrm{C}$

6. Am atau spektrum massa $=1.5$

Untuk mengetahui parameter PV yang digunakan maka diperlukan yang namanya pemodelan matematis yang di rangkai menjadi rangkaian ekivalen [1], [10]. Berikut gambar rangkaian ekivalen :

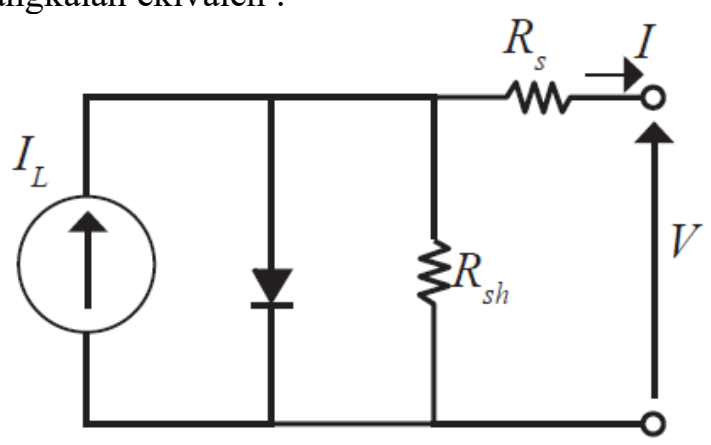

Gambar 2. Rangkaian ekivalen panel surya

Dari rangkaian ekivalen yang diperoleh hubungan arus dan tegangan sel surya yang ditunjukkan pada persamaan (1) [1], [10].

$$
I=I_{L}-I_{O}\left[\exp \left(\frac{V+R_{S} \cdot I}{V_{t} a}\right)-\frac{V+R_{S}}{R_{s h}}\right]
$$

Keterangan :

$I_{L}=$ Arus yang dibangkitkan cahaya (A)

$I_{O}=$ Arus saturasi dioda $\mathrm{p}-\mathrm{n}(\mathrm{A})$

$R_{S}=$ resistor seri pada sel PV $(\mathrm{Ohm})$

$R_{S h}=$ Resistor paralel sel PV (Ohm)

$\mathrm{a}=$ parameter dioda bernilai antara $1 \& 2$

$V=$ Tegangan terminal $(\mathrm{V})$.

$\mathrm{V}$ (tegangan terminal) dinyatakan dengan persamaan berikut ini [1]:

$$
V_{t}=N_{S} \frac{k T}{q}
$$

Keterangan :

$T=$ temperatur $(\mathrm{K})$

$K=$ Konstanta Boltzman $\left(1.3806 \times 10^{-22} \mathrm{~J} / \mathrm{K}\right)$ $q=$ Muatan elektron $\left(1.6021 \times 10^{-19} \mathrm{C}\right)$

$R_{P}=$ Resistor shunt atau resistor paralel menunjukkan arus bocor pada sambungan p-n dioda yang ber nilai $0.1-10 \mathrm{~m}^{2}$.

Efisiensi PV merupakan ukuran output daya listrik terhadap energi matahari dan berbanding dengan luas yang jatuh pada permukaan PV dalam satuan Watt, yang dinyatakan menggunakan persamaan (3) berikut [11], [12]:

$$
\eta_{\max }=\frac{P \max }{E_{s w . s y} \mathrm{x} \mathrm{A}_{\mathrm{C}}}
$$

Keterangan :

$\mathrm{P}_{\max } \quad=$ Daya keluaran maksimal $\left(\mathrm{V}_{\mathrm{Im}} \times \mathrm{I}_{\mathrm{Im}}\right)$ (Watt)

AC $=$ Luas permukaan Cell $\left(\mathrm{m}^{2}\right)$

E sw.sy $=1000 \mathrm{Watt} / \mathrm{m}^{2}$. Koefesien incident radiation flux dalam standard test conditions (STC) $\left(\mathrm{W} / \mathrm{m}^{2}\right)$

Perhitungan Fill Factor (FF) merupakan salah satu parameter untuk meningkatkan efisiensi PV. Semakin tinggi nilai FF maka kerja PV semakin baik. Berikut merupakan rumus nilai FF [12]-[14]:

$$
F F=\frac{V_{\text {max }} \cdot I_{\text {max }}}{\mathrm{V}_{\mathrm{OC}} \cdot \mathrm{I}_{\mathrm{SC}}}
$$

Perhitungan daya Input dengan persamaan (5) dan daya Output dengan persamaan (6) [11], [15], [16]:

$$
P_{i n}=I r \cdot A
$$

Keterangan :

$\mathrm{P}$ input $=$ Daya input akibat irradiance matahari (Watt)

Ir $=$ Intensitas radiasi matahari $\left(\mathrm{Watt} / \mathrm{m}^{2}\right)$

A $\quad=$ Luas area permukaan $\mathrm{PV}\left(\mathrm{m}^{2}\right)$.

$$
P_{\text {out }}=V_{O C} \cdot I_{S C} \cdot F F
$$

Keterangan :

$\mathrm{P}$ output $=$ Daya yang dibangkitkan oleh solar cell

$\mathrm{V}_{\mathrm{OC}} \quad=$ Tegangan rangkaian terbuka pada solar cell

$\mathrm{I}_{\mathrm{SC}} \quad=$ Arus hubung singkat pada solar cell

$\mathrm{FF} \quad=$ Fill Factor $]$.

Estimasi pencapaian daya yang diinginkan dari prototype ini, dapat diukur 
SainETIn (Jurnal Sain, Energi, Teknologi \& Industri), Vol. 5 No. 1, Desember 2020, pp. 8 - 16 ISSN 2548-6888 print, ISSN 2548-9445 online

dengan menghitung efisiensi konversi energi cahaya matahari menjadi energi listrik. Berikut persamaan dari efisiensi konversi:

$$
\eta=\frac{P_{\text {In }}}{P_{\text {Out }}} 100 \%
$$

\subsubsection{Charger Controller}

Charger controller yang digunakan pada penelitian ini yakni menggunakan versi prototype dengan menggunakan charger baterai vape. Output charger adalah $4.2 \mathrm{~V}$ sedangkan baterai hanya $3.7 \mathrm{~V}$, agar dapat mengisi baterai secara optimal. Berikut spesifikasi charger :
1. $\mathrm{V}_{\text {Input }}=5 \mathrm{~V}$
2. $\mathrm{I}_{\text {Input }}=2 \mathrm{VA}$
3. $\mathrm{V}_{\text {Output }}=4.2 \mathrm{~V}$
4. $\mathrm{I}_{\text {Output }}=1 \mathrm{~A}$

\subsubsection{Modul Stepdown}

Modul step down digunakan untuk menurunkan tegangan yang dihasilkan oleh PV. Tegangan max yang dihasilkan PV adalah $18 \mathrm{~V}$, sedangkan pada spesifikasi tegangan max charger cotroller hanyalah $5 \mathrm{~V}$. ini dilakukan agar menjaga charger tidak cepat rusak, begitu juga pada beban. Berikut spesifikasi modul stepdown:

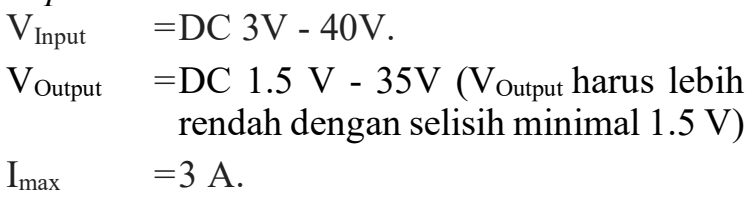

Dimensi $=42 \mathrm{~mm} \times 20 \mathrm{~mm} \times 14 \mathrm{~mm}$.

\subsubsection{Batterai IMR 18650}

Pada prototype ini batterai berguna untuk menyimpan kelebihan daya ketika daya beban rendah dan dapat menyuplai daya yang bersamaan dengan keluaran daya panel ketika kebutuhan beban tinggi. Baterai disusun secara paralel utuk menambah Ah. Berikut spesifikasi baterai :

$$
\begin{aligned}
& \text { Kapasitas }=2500 \mathrm{mAh}, 3,5 \mathrm{~A}, 3,7 \mathrm{~V} \\
& \text { Max continiuous discharge }=20 \mathrm{~A} \\
& \text { Max pulse discharge }=35 \mathrm{~A}
\end{aligned}
$$

\subsubsection{Sensor Arus}

Modul sensor Arus berguna untuk mengukur perubahan arus AC dan DC terkhusus pada prototype ini yakni arus DC. Sensor arus dengan seri ACS712-5 AC-DC 5A Hall Current Sensor Module.
Dalam penggunannya, sensor ini dipasang secara seri serta dapat mengukur arus positif dan negatif dari -5 A hingga $5 \mathrm{~A}$, dan memerlukan inputan daya sebesar $5 \mathrm{~V}$. Untuk pembacaan nilai tengah atau $0 \mathrm{~A}$ maka harus di kalibrasi atau di set dari setengah nilai $\mathrm{Vcc}=5 \mathrm{~V}$ yakni $2.5 \mathrm{~V}$. Modul ACS712 memiliki tingkat sensitifitas sebesar $400 \mathrm{mV} / \mathrm{A}$ [1], [17], pada Gambar 3 merupakan rangkaian sensor arus.

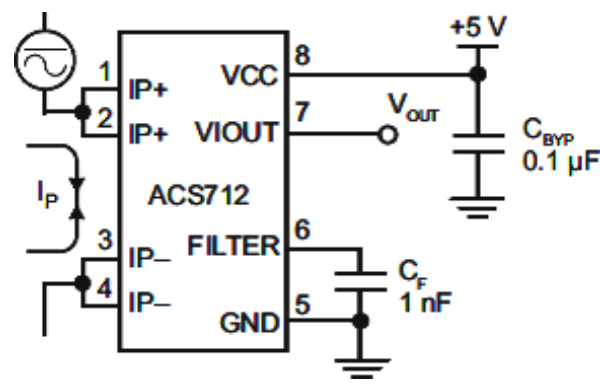

Gambar 3. Rangkaian sensor arus ACS712

Spesifikasi sensor arus ACS712 adalah sebagai berikut :

1. Supply Voltage $\mathrm{V}_{\mathrm{CC}}=5 \mathrm{~V}$

2. Arus pengukuran $=-30$ to $30 \mathrm{Amps}$

3. Vout nominal $(0 \mathrm{~A})=\mathrm{V}_{\mathrm{CC}} / 2\left(2,5 \mathrm{~V} \rightarrow \mathrm{V}_{\mathrm{CC}}=5\right.$ V)

4. Skala pengukuran $=185 / \mathrm{Amp}$

5. Chip ACS712ELC-05A SOP-8

\subsubsection{Sensor Tegangan}

Modul sensor tegangan berguna untuk mendeteksi dan mengukur tegangan dengan seri voltage DC $0-25 \mathrm{~V}$.

Dengan prinsip pembagi tegangan yang dapat mengurangi tegangan input hingga $5 \mathrm{kali}$ dari tegangan asli, dengan $\mathrm{V}$ analog maksimum mikrokontoler yaitu $5 \mathrm{~V}$ sehinggat tidak boleh diberi masukan melebihi 5 x $5 \mathrm{~V}$ atau sebesar 25 V. Pada prototype ini, sensor tegangan dipasang secara paralel dari panel surya. Rangkaian modul sensor tegangan adalah seperti pada Gambar 4a [1].

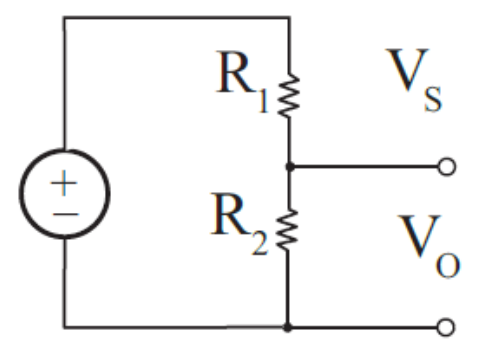

Gambar 4a. Rangkaian sensor tegangan 
SainETIn (Jurnal Sain, Energi, Teknologi \& Industri), Vol. 5 No. 1, Desember 2020, pp. 8 - 16 ISSN 2548-6888 print, ISSN 2548-9445 online

Rangkaian modul sensor tegangan yang terhubung dengan PV pada Gambar 4b.

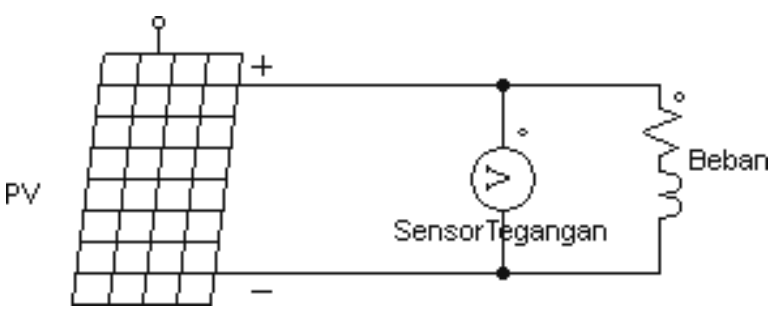

Gambar 4b. Rangkaian sensor tegangan yang terhubung pararlel dengan PV [1]

Berikut spesifikasi sensor tegangan :

1. Tegangan input $=0-25 \mathrm{~V} \mathrm{DC}$

2. Tegangan deteksi $=0.02445-25 \mathrm{~V}$ DC

3. Ketelitian pengukuran $=0.00489 \mathrm{~V}$

4. Ukuran $=25 \times 13 \mathrm{~mm}$

\subsubsection{Arduino Uno}

Dengan menggunakan spesifikasi perangkat pin output $5 \mathrm{~V}$, dan GND, dengan port A0, A1, dan A2.

\subsubsection{Bread Board/Papan Roti}

Papan Roti yang berukuran 7 × $5 \mathrm{~cm}$. Digunakan untuk standing lamp/beban yang disusun secara paralel dengan tujuan menghemat daya battrai yang tersimpan.

\subsubsection{Lampu LED 12 V 10 Watt}

Sebanyak 3 buah lampu LED digunakan yang disusun di atas papan roti secara paralel agar menghemat tegangan pada battrai dan menghabiskan daya. V output dari batrrai adalah $3.7 \mathrm{~V}$, namun dapat menyala di tegangan $12 \mathrm{~V}$ karena lampu bersifat halogen yang dapat nyala pada tegangan $3.7 \mathrm{~V}$. berikut spesifikasi lampu LED :

$$
\begin{aligned}
& \mathrm{V} \text { lampu }=12 \mathrm{~V} \\
& \text { I lampu }=10 \mathrm{Watt} \\
& \text { R lampu }=10.3 \mathrm{Ohm}
\end{aligned}
$$

\subsection{Perancangan Alat}

Perancangan yang dilakukan dengan menggunakan panel sel surya $10 \mathrm{Wp}$ sebagai penghasil energi listrik dari energi matahari. Baterai dibutuhkan sebagai penyimpanan energi listrik yang dihasilkan dari panel sel surya. Pengontrol penyimpanan ke baterai diatur oleh sebuah kontroler, tujuan dari kontroler adalah sebagai penghubung serta pemutus pengisian energi listrik dari sel surya ke baterai.
Keluaran dari sel surya berupa arus DC yang kemudian akan dialirkan ke beban lampu, setiap keluaran tegangan dan arus dari battrai akan dideteksi dan diukur oleh sensor arus dan tegangan lalu menjadi input-an pada aduino uno dan output akan tampil pada aplikasi arduino di pc.

Pada perancangan ini merupakan analisa atau perkiraan berapa output daya yang akan dibangkitkan oleh prototype sebelum melakukan uji coba dengan menggunakan pemodelan matematis berikut:

1. Perhitungan estimasi nilai daya yang dapat dibangkitkan oleh PV 10 WP, dengan menggunakan persamaan (3), didapatkan nilai efisiensi sebagai berikut :

$$
\eta_{\max }=\frac{P \max }{E_{\text {sw.sy }} \times \mathrm{A}_{\mathrm{C}}}
$$

$$
\begin{aligned}
\eta_{\max } & =\frac{P_{\max }}{E_{\text {sw.sy }} x A_{C}} x 100 \% \\
& =\frac{18.52 \mathrm{~V} \cdot 0.54 \mathrm{~A}}{1000 \mathrm{~W} / \mathrm{m}^{2} \cdot(0.350 \mathrm{~m} \cdot 0.290 \mathrm{~m})} \times 100 \% \\
& =\frac{10 \mathrm{~W}}{101.5 \mathrm{~W}} 100 \% \\
& =0.0985 \cdot 100 \% \\
& =9.85 \%
\end{aligned}
$$

2. Perhitungan Fill Factor (FF) berdasarkan persamaan (4) :

$$
\begin{aligned}
F F & =\frac{V \max \cdot \operatorname{Im} a x}{V_{O C} \cdot I_{S C}} \\
& =\frac{18.52 \mathrm{~V} \cdot 0.54 \mathrm{~A}}{22.22 \mathrm{~V} \cdot 0.58 \mathrm{~A}} \\
& =\frac{10.0008 \mathrm{VA}}{12.8876 \mathrm{VA}} \\
& =0.776
\end{aligned}
$$

3. Perhitungan $\mathrm{P}_{\text {In }}$ berdasarkan persamaan (5):

$$
\begin{aligned}
P_{I n} & =I r \cdot A c \\
& =1000 \mathrm{~W} / \mathrm{m}^{2} \cdot 0.350 \mathrm{~m} \cdot 0.290 \mathrm{~m} \\
& =101.5 \mathrm{Watt}
\end{aligned}
$$

4. Perhitungan $\mathrm{P}_{\text {Out }}$ berdasarkan persamaan (6) :

$$
\begin{aligned}
P_{\text {Out }} & =V_{\text {OC }} \cdot I_{S C} \cdot F F \\
& =22.22 \mathrm{~V} \cdot 0.58 \mathrm{~A} \cdot 0.776 \\
& =10.0007 \mathrm{Watt}
\end{aligned}
$$

5. Perhitungan efisiensi konversi : 
SainETIn (Jurnal Sain, Energi, Teknologi \& Industri), Vol. 5 No. 1, Desember 2020, pp. 8 - 16 ISSN 2548-6888 print, ISSN 2548-9445 online

$$
\begin{aligned}
\eta & =\frac{P_{\text {Out }}}{P_{I n}} 100 \% \\
& =\frac{10.0007 \mathrm{Watt}}{101.5 \mathrm{Watt}} 100 \% \\
& =9.852 \%
\end{aligned}
$$

6. Block Diagram perancangan prototype penelitian ini adalah sebagaimana terlihat pada Gambar 5:

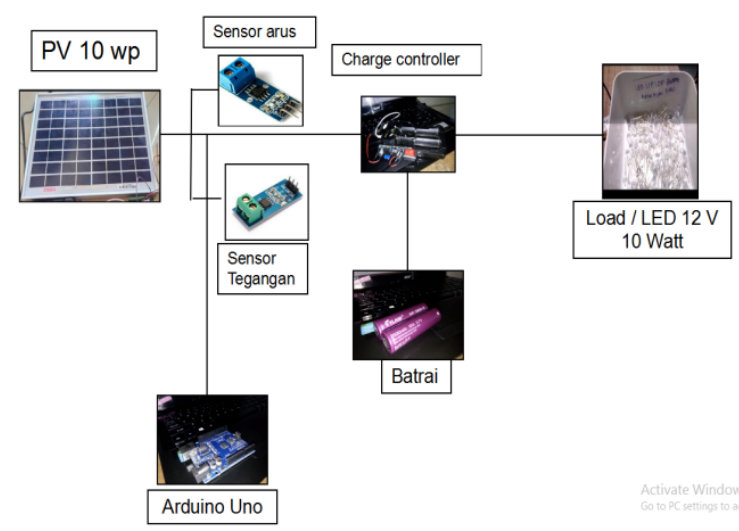

Gambar 5. Block Diagram perancangan prototype penelitian

\subsection{Perakitan Komponen}

Setelah dilakukan perancangan alat, maka langkah selanjutnya adalah dilakukan perangkaian komponen. Rangkaian prototype dari sistem yang dibuat adalah sebagaimana ditunjukkan pada Gambar 6 berikut :

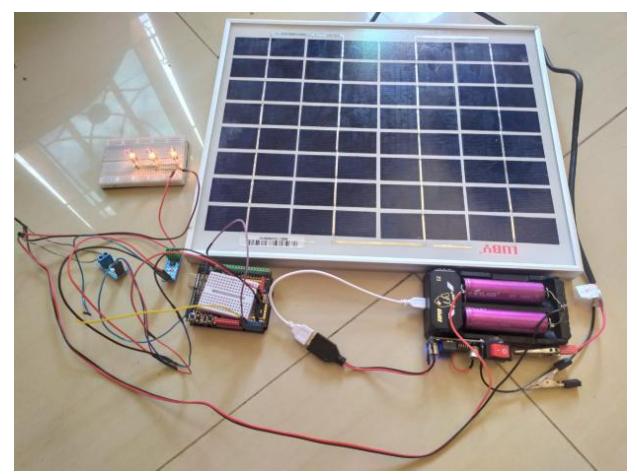

Gambar 6. Rangkaian prototype PV

Program coding pada software arduino seperti terlihat pada Gambar 7 berikut:

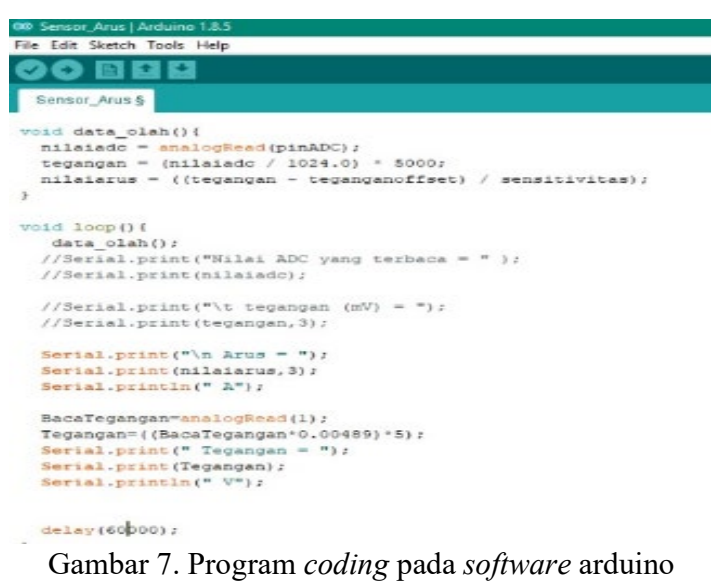

\section{HASIL DAN PEMBAHASAN}

\subsection{Data Perbandingan Penjemuran PV}

\subsubsection{Menggunakan Beban}

Data lama penjemuran 1 jam (Sabtu, 21 April 2020 Di Samarinda), seperti Tabel 1a dan pada Gambar 8a.

Tabel 1a. Penjemuran 1 jam dengan beban dengan delay 30 menit menggunakan beban

\begin{tabular}{cccccc}
\hline No & Jam & \multicolumn{2}{c}{ Batrai } & \multicolumn{2}{c}{ Panel } \\
& (WITA) & V & I & V & I \\
\hline 1 & 14.12 & 2.96 & 0.06 & 16.30 & 0.48 \\
2 & 14.42 & 3.33 & 0.3 & 17.03 & 0.38 \\
3 & 15.12 & 3.50 & 0.42 & 17.23 & 0.40 \\
4 & 15.42 & 4.26 & 0.30 & 17.42 & 0.34 \\
5 & 16.12 & 4.25 & 0.65 & 16.77 & 0.05 \\
\hline
\end{tabular}

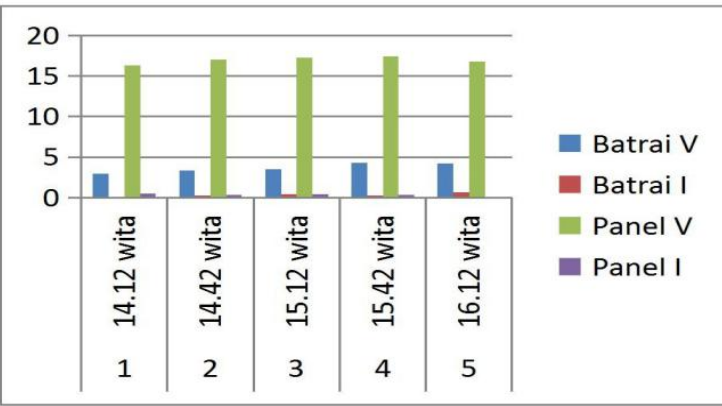

Gambar 8a. Grafik penjemuran PV selama 1 jam dengan delay 30 menit menggunakan beban

Data lama penjemuran 2 jam (Selasa , 21 April 2020 Di Samarinda), seperti Tabel 1b dan pada Gambar 8b. 
SainETIn (Jurnal Sain, Energi, Teknologi \& Industri), Vol. 5 No. 1, Desember 2020, pp. 8 - 16 ISSN 2548-6888 print, ISSN 2548-9445 online

Tabel 1b. Penjemuran 2 jam dengan beban dengan delay 15 menit menggunakan beban

\begin{tabular}{cccccc}
\hline No & Jam & \multicolumn{2}{c}{ Batrai } & \multicolumn{2}{c}{ Panel } \\
& (WITA) & V & I & V & I \\
\hline 1 & 7.50 & 3.13 & 0.02 & 18.27 & 0.22 \\
2 & 8.05 & 2.98 & 0.32 & 17.03 & 0.33 \\
3 & 8.30 & 3.54 & 0.38 & 17.15 & 0.42 \\
4 & 8.45 & 3.35 & 0.32 & 16.58 & 0.35 \\
5 & 9.00 & 3.48 & 0.68 & 18.07 & 0.15 \\
\hline
\end{tabular}

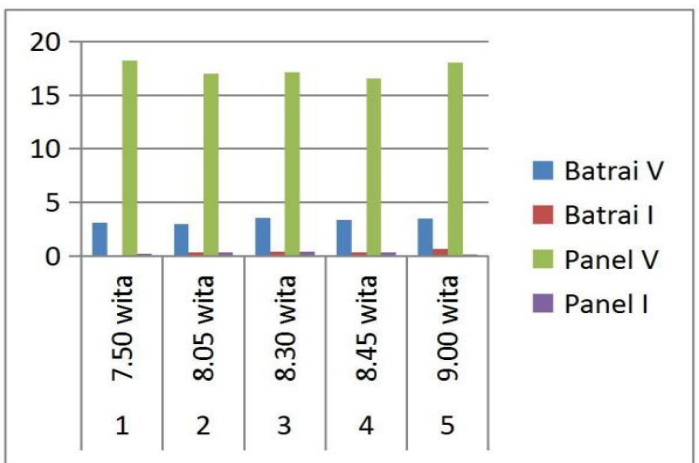

Gambar 8b. Grafik penjemuran PV selama 2 jam dengan delay 15 menit menggunakan beban

\subsubsection{Tanpa Menggunakan Beban}

Data lama penjemuran 1 jam (Sabtu, 30 Mei 2020 Di Anggana), seperti Tabel 2a dan pada Gambar 9a.

Tabel 2a. Penjemuran 1 jam dengan beban dengan delay 30 menit tanpa beban

\begin{tabular}{cccc}
\hline \multirow{2}{*}{ No } & \multirow{2}{*}{ Jam (WITA) } & V Panel \\
& & V & I \\
\hline 1 & 10.12 & 16.42 & 1.50 \\
2 & 10.42 & 16.50 & 1.42 \\
3 & 11.12 & 17.25 & 1.40 \\
4 & 11.42 & 17.42 & 2.50 \\
5 & 12.12 & 18.66 & 2.55 \\
\hline
\end{tabular}

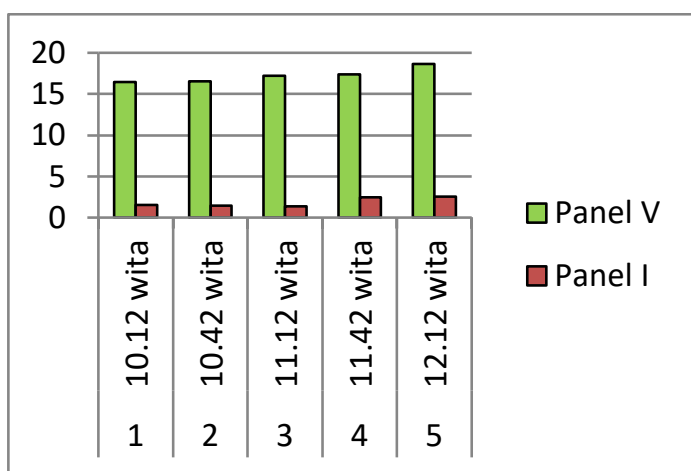

Gambar 9a. Grafik penjemuran PV selama 2 jam dengan delay 30 menit tanpa beban
Data lama penjemuran 2 jam (Minggu, $31 \mathrm{Mei}$ 2020 Di Anggana), seperti Tabel 2b dan pada Gambar 9b.

Tabel 2b. Penjemuran 2 jam dengan beban dengan delay 15 menit menggunakan beban

\begin{tabular}{cccc}
\hline \multirow{2}{*}{ No } & \multirow{2}{*}{ Jam (WITA) } & \multicolumn{2}{c}{ Panel } \\
& & $\mathrm{V}$ & $\mathrm{I}$ \\
\hline 1 & 9.50 & 17.33 & 1.17 \\
2 & 10.05 & 17.35 & 1.36 \\
3 & 10.30 & 17.47 & 1.33 \\
4 & 10.45 & 17.50 & 2.30 \\
5 & 11.00 & 18.36 & 2.40 \\
\hline
\end{tabular}

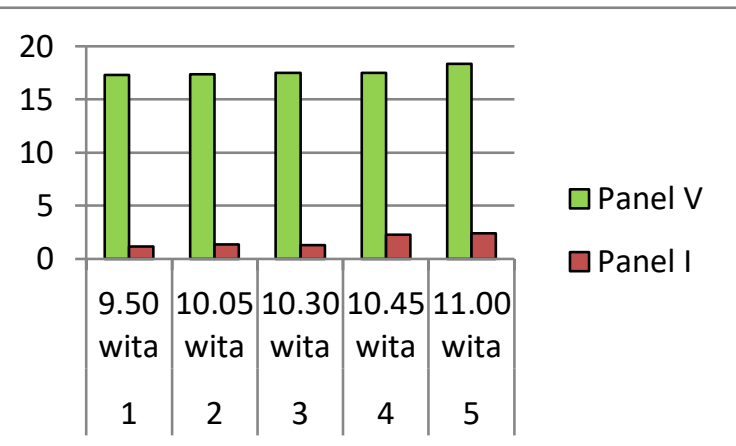

Gambar 9b. Grafik penjemuran PV selama 2 jam dengan delay 15 menit tanpa beban

Dari pemodelan matematis nilai efisiensi didapatkan nilai 9.85\%, dengan nilai Fill Factor sebesar 0.776. Nilai FF hampir mencapai nilai 1, sedangkan biasanya nilai FF sekitar 0.7-0.85, yang menunjukkan nilai FF tidak terlalu rendah, sehingga dapat meningkatkan nilai efisiensi PV itu sendiri. Didapatkan nilai $\mathrm{P}_{\mathrm{In}}$ sebesar 101.5 Watt, dengan nilai $\mathrm{P}_{\text {Out }} 10.0007$ Watt. Sehingga didapatkan nilai efisiensi daya PV bernilai 9.82\%. Semakin besar nilai efisiensi PV maka semakin baik pula kinerja PV dalam mengkonversi cahaya matahari menjadi energi listrik.

Dari data 1 (menggunakan beban) dan 2 (tanpa menggunakan beban) yang telah ada dapat dijelaskan bahwa data 1 dengan lama penjemuran 1 jam dengan delay 30 menit didapatkan nilai $\mathrm{V}$ panel bergerak naik turun karena penggunaan beban, namun perbedaan $\mathrm{V}$ yang tidak terlalu kontras. Didapatkan nilai I panel tidak stabil, dan lebih kontras, hal ini sangat real, sehingga penggunaan sensor arus ACS712-5 A tidak direkomendasikan digunakan dalam prototype berskala besar. Namun terlihat kontras pada data $\mathrm{V}$ dan I baterai, hal ini terjadi karena penggunaan modul step-down, agar 
penggunaan charger controller, battrai, dan lampu tidak meledak karena $\mathrm{V}$ dan I input yang lebih rendah. Pengambilan data lama penjemuran 2 jam dengan delay 15 menit menggunakan beban, didapatkan tidak terlalu jauh berbeda dengan data lama penjemuran 1 jam. Karena nilai awal V dan I output pada PV yang hampir sama, begitu pula nilai $\mathrm{V}$ dan I output pada battrai. Didapatkan pula nilai $\mathrm{V}$ dan I PV sangat kontras pula dengan nilai V dan I battrai karena penggunaan modul step-down.

Dari data 2 (tanpa menggunakan beban), dengan lama penjemuran 1 jam delay 30 menit didapatkan nilai $\mathrm{V}$ dan I output panel terlihat meningkat konstan, begitu pula pada lama penjemuran 2 jam delay 15 menit.Tabel yang hanya disajikan data V dan I output PV karena battrai di sini bersihat sebagai beban pula.

\section{KESIMPULAN}

1. Didapatkan nilai efisiensi PV sebesar $9.85 \%$, dengan nilai FF sebesar 0.776 yang menunjukkan nilai FF yang tidak rendah. Didaptkan juga nilai efisiensi daya sebesar 9.82\% yang tidak jauh dari nilai efisiensi PV. Namun nilai tersubut masih jauh dari nilai $100 \%$ karena adalanya losses atau adanya rugi-rugi daya atau kondisi yang merupakan salah satu faktor adanya losses yang mengakibatkan hilangnya beberapa energi output.

2. Dari data lama penjemuran 1 dan 2 jam pada PV menggunakan beban, terlihat $\mathrm{V}$ dan I lebih rendah dari data lama penjemuran 1 dan 2 jam tanpa menggunakan beban, karena $\mathrm{V}$ dan I output PV tidak terserap oleh beban.

\section{UCAPAN TERIMA KASIH}

Kami mengucapkan banyak terimaksih kepada Ir. Nur Rani Alham, S.Pd., MT., selaku dosen pengampu mata kuliah Sistem Instrumentasi pada semester IV Genap Tahun 2019/2020 yang telah memberikan kontribusi tenaga dan waktu demi tercapainya tujuan jurnal ini. Kami juga mengucapkan banyak terimakasih kepada pihak media Jurnal Sains, Energi, Teknologi \& Industri (SainETIn) Universitas Lancang Kuning Pekanbaru yang bersedia sebagai media publikasi jurnal ilmiah ini. Demikian ucapan terimakasih ini kami sampaikan.

\section{DAFTAR PUSTAKA}

[1] M. R. Fachri, I. D. Sara, and Y. Away, "Pemantauan Parameter Panel Surya Berbasis Arduino Secara Real Time," Jurnal Rekayasa Elektrika, vol. 11, no. 4, pp. 123-128, 2015.

[2] N. P. Novri, "Kajian Pemanfaatan Energi Panas Buang Tungku Pembakaran Bakso Bakar sebagai Sumber Energi Listrik Menggunakan Termoelektrik Generator," Skripsi Prodi Teknik Elektro, Universitas Andalas, 2019.

[3] S. Wilman, F. Dimas, and A. Mega, Pembuatan Prototipe Solar Cell Murah dengan Bahan Organik-Inorganik (Dyesensitized Solar Cell). Bandung: ITB, 2007.

[4] R. Prasetyowati, "Sel Surya Berbasis Titania Sebagai Sumber Energi Listrik Alternatif," in Seminar Nasional Penelitian, Pendidikan dan Penerapan MIPA, 2012.

[5] H. Eteruddin, A. Atmam, and D. Setiawan, "The Impact of Solar Panel Temperature to Solar Home System (SHS) Output Voltage," IOP Conference Series: Earth and Environmental Science, vol. 469, no. 1, 2020.

[6] D. Setiawan, H. Eteruddin, and L. Siswati, "Sistem Pembangkit Listrik Tenaga Surya untuk Tanaman Hidroponik," Jurnal Teknik, vol. 14, no. 2, pp. 208-215, 2020.

[7] H. Eteruddin, D. Setiawan, Atmam, and B. Nasution, "Solar home system with diversified roofing construction," Universal Journal of Electrical and Electronic Engineering, vol. 6, no. 5, pp. 351-358, 2019.

[8] H. Eteruddin, D. Setiawan, and A. Atmam, "Web Based Raspberry Monitoring System Solar Energy Power Plant," IOP Conference Series: Earth and Environmental Science, vol. 469, no. 1, 2020.

[9] A. M. Ghazali et al., Fikih Energi Terbarukan: Pandangan dan respons Islam atas pembangkit listrik tenaga surya (PLTS). Yogyakarta: Lakpesdam-PBNU, 2017.

[10] D. Hamdani, K. Subagiada, and L. Subagio, "Analisis Kinerja Solar Photovoltaic System (SPS) Berdasarkan Tinjauan Efisiensi Energi dan Eksergi," J. Mater. dan Energi Indones., vol. 1, no. 2, pp. 84 - 92, 2011. 
SainETIn (Jurnal Sain, Energi, Teknologi \& Industri), Vol. 5 No. 1, Desember 2020, pp. 8 - 16 ISSN 2548-6888 print, ISSN 2548-9445 online

[11] S. P. Sukhatme and J. K. Nayak, Solar Energy Principles of Thermal Collection and Storage. New Delhi: McGraw-Hill Education, 2008.

[12] R. K. Satpathy and V. Pamuru, Solar PV Power: Design, Manufacturing and Applications from Sand to Systems. London: Elsevier Science, 2020.

[13] H. J. Moller, Semiconductors for Solar Cells. London: Artech House, Inc., 1993.

[14] M. Poliskie, Solar Module Packaging Polymeric Requirements and Selection. Boca Raton: CRC Press, 2011.
[15] R. Wibowo, "Studi Penggunaan Solar Reflector Untuk Optimalisasi Output Daya Pada Photovoltaic Modul," Universitas Kristen Petra, Surabaya, 2009.

[16] V. Yumanda and S. Sidopekso, "Pengaruh Penggunaan Cermin Datar dalam Ruang Tertutup pada Sel Surya Silikon," J. Fis. dan Apl., vol. 6, no. 1, pp. 1-4, 2010.

[17] Data sheet ACS712, "Fully Integrated, Hall-Effect-Based Linear Current Sensor IC with $2.1 \mathrm{kVRMS}$ Isolation and a LowResistance Current Conductor,” 2020. 